\title{
Optimal Conditions of Paint Wastewater Coagulation With Gastropod Shell Conchiolin Using Response Surface Design and Artificial Neural Network-Genetic Algorithm
}

M.I Ejimofor ( $\square$ mi.ejimofor@unizik.edu.ng )

Nnamdi Azikiwe University

\section{I.G Ezemagu}

Nnamdi Azikiwe University

M.C Menkiti

Nnamdi Azikiwe University

V.I Ugonabo

Nnamdi Azikiwe University

\section{B.U Ejimofor}

University of Nigeria Nsukka

\section{Research Article}

Keywords: Paint wastewater, Coagulation, Gastropod shell, bio-coagulant, RSD, ANN-GA

Posted Date: January 12th, 2022

DOI: https://doi.org/10.21203/rs.3.rs-1217715/v1

License: (c) (1) This work is licensed under a Creative Commons Attribution 4.0 International License.

Read Full License 


\section{Abstract}

The potential of gastropod shell conchiolin (GSC) (a waste product of the deprotenization stage of chitosan production) as one of the alternatives to chemical coagulants has been explored for treatment

of paint industrial wastewater (PW). The accuracy of response surface design (RSD) and the precision of artificial intelligence (Al) in predicting and optimizing the process conditions were harnessed in raising experimental design matrix and response optimization, respectively for the bench scale jar test coagulation experiment. PW was characterized using American public health association (APHA) standard methods. Extraction of conchiolin was done via alkaline extraction method. PW contains $2098 \mathrm{mg} / \mathrm{l}$ total suspended solid (TSS) above discharge limit $(1905 \mathrm{mg} / \mathrm{l})$. Fourier transform infrared (FTIR) spectrum of GSC revealed a broad N-H wagging band at $750-650 \mathrm{~cm}^{-1}$ indicating the presence of secondary amine linked to the presence of protein. Turbidity removal from $\mathrm{PW}$ via one factor at a time (OFAT) was found to be a function of $\mathrm{pH}, \mathrm{GSC}$ dosage, temperature and time. Artificial neural network (ANN) response prediction shows $92 \%$ correlation with the response surface design (RSD) experimental result. The optimal conditions obtained via genetic algorithm (GA) for the response optimization at the best $\mathrm{pH}$ of 4 indicate optimal turbidity removal of $98 \%$ at GSC dosage, time and temperature of $4 \mathrm{~g}, 20$ min and $45^{\circ} \mathrm{C}$, respectively.

\section{Introduction}

Wastewater management describes a general and comprehensive methodology for treatment, discharge or reuse of contaminated domestic or industrial wastewater [1]. Specifically, industrial wastewater management uses systematic methods in decontamination of toxic contaminants in industrial wastewaters to conform to the general acceptable discharge standard [1, 2]. In chemical industries, paint manufacturing industry is among the industries that generate large volume of wastewater [3]. Majorly, the wastewater from paint industry comes from batch wash-off. Paint wastewater contains colloidal particles $[3,4]$ and is also very rich in calcium [4]. These colloidal particles make the wastewater very turbid and of poor quality $[5,6]$. Discharge of poor quality wastewater into the watershed poses health risk $[5,6,7,8]$. Also, disposing paint wastewater on land will contaminate the land by introducing unwanted contaminants that can affect the soil fertility [8]. Proper treatment of paint wastewater can be achieved by decontamination of the colloidal particles $[3,8,9]$. Researches have been conducted on particles decontamination from wastewaters using different methods such as adsorption [10,11], reverse osmosis[12], sedimentation[13], filtration [14] and ultra-filtration [15], etc. More recent studies reported high particles removal efficiency through coagulation-flocculation $[16.17,18]$. Coagulation-flocculation process of wastewater treatment involves destabilization of stable negatively charged suspended particles within the wastewater sample by introducing counter charged (positively charged) coagulants [19]. Effective interactions between the negatively charged particles and the coagulants result in charge neutralization, inter-particle bridging, particles double layer compression and sweep flocculation [20]. The combined effects of these stages leave behind clarified wastewater samples and settled sludge. 
The use of synthetic chemical coagulants such as alum, poly-aluminum chloride and ferric chloride for coagulation experiment have been successfully carried out by many researchers [21, 22]. However, the disadvantages of chemical coagulants which include; increase in $\mathrm{pH}$ of treated wastewater, generation of large volume of sludge, high risk of Alzheimer's infection, high cost of residual sludge management, the cost of the coagulants and toxicity level of the generated sludge[23] have been major limitations to the use of chemical coagulants. Hence, the need for alternative opened up new research interests on natural or bio-coagulants [23, 24]. Extracts from shells (snail shell chitosan) [25], Periwinkle shell extract [16], plant based coagulants (moringa) [26], mucuna seed extract [27, 28] have been successfully used in wastewater treatment as bio-coagulants. More precursors are still under investigation of which this work has been able to harness and study one (gastropod shells from livestock farming).

In livestock farming, production and processing of gastropods generate large quantity of shells as waste products. These agricultural wastes can be processed to chitosan through deproteinization and demineralization [29]. During the deprotenization stage, some loosely attached proteins (conchiolin) are removed [29]. These proteins are disposed as waste products.

Hence, proper utilization of this waste-product of chitosan production has been a gap that needs to be addressed. This work therefore was conducted to close this gap. The potentials of conchiolin as coagulant have been accessed in treatment of paint wastewater. Also, due to the robustness of response surface design (RSD), and the proven optimization efficiency of artificial intelligence (genetic algorithm) [30], hybrid method (the use of RSD and ANN-GA) was explored for experimental design and optimization of the process response for reduction of colloidal particles in paint wastewater.

\section{Materials And Methods}

\subsection{Materials}

This work used wastewater generated from production of water-based emulsion paint, concentrated coagulants extracted from gastropod shell (conchiolin) and analytical grade $\mathrm{NaOH}$.

\subsubsection{Materials collection}

The paint wastewater sample was collected after batch wash-off from a paint factory in Onitsha, Anambra State Nigeria in March, 2016. The gastropod shells for the extraction of the natural coagulant were source from farmer's livestock market in Onitsha while the reagents were bought from Bridge head market Onitsha.

\subsubsection{Characterization of paint wastewater}

The paint wastewater sample was characterized using standard methods. Table 1 shows the parameters and their standard testing methods. 
Table 1: Parameter testing methods for paint wastewater

\begin{tabular}{lllc}
\hline S/No & Parameter & Referred standard methods & Reference. \\
\hline 1 & Temperature $\left({ }^{\circ} \mathrm{C}\right)$ & SMWW, 2550 (2012) & {$[31]$} \\
\hline 3 & $\mathrm{PH}$ & SMWW, 2320A, (2012) & {$[31]$} \\
\hline 3 & Total suspended solid (mg/L) & APHA, 2540D (1995) & {$[32]$} \\
\hline 4 & Total dissolved solid (mg/L) & APHA 2540 C (1995) & {$[32]$} \\
\hline 5 & Total solid (mg/L) & AWWA, 205 (1985) & {$[33]$} \\
\hline 6 & Turbidity (NTU) & & \\
& & SMWW, 2130B (2012) & {$[31]$}
\end{tabular}

AWWA: American water works association, APHA: American public health association, SMWW: standard method for examination of water and wastewater

\subsubsection{Extraction of conchiolin from gastropod shell floor}

The gastropod shell conchiolin (GSC, chito-protein) was extracted from gastropod shells using slight modification of the method described by $[29,30]$. $1500 \mathrm{~g}$ of gastropod shells were washed, sun dried, crushed and sieved using $0.6 \mathrm{~mm}$ sieve to obtain gastropod shell flour (GSF). The sieved flour was deproteinized using $3.5 \%(\mathrm{w} / \mathrm{v})$ of dilute sodium hydroxide $(\mathrm{NaOH})$ solution [30]. The GSF and the sodium hydroxide solution were mixed in solid - liquid ratio of 1:10 (w/v) in $500 \mathrm{~mL}$ beaker. The mixture was stirred (using magnetic stirrer) for $2 \mathrm{~h}$ at a constant temperature of $65^{\circ} \mathrm{C}$. During this stage, there was mild formation of foam that eventually receded after few minutes. After the $2 \mathrm{~h}$ stirring time, the mixture was cooled to room temperature. The cooled mixture was filtered with filter sack set-up to separate the liquid extract containing the gastropod shell conchiolin (GSC). The filtrate was allowed to settle for $40 \mathrm{~min}$ before decantation. The conchiolin obtained after decanting the clear extraction solution was sun dried for two days, ground and stored in an air tight container for use as coagulant. Figure 1, shows the graphical representation of the process route. Before use, the conchiolin sample was subjected to physiochemical analysis to obtain the proximate composition using the standard method as shown in Table 2. 
Table 2: Characterization procedure for the coagulant (conchiolin)

\begin{tabular}{llll}
\hline S/No & Parameters & Procedure & Reference \\
\hline 1 & Yield $(\%)$ & AOAC (1995) & {$[34]$} \\
\hline 2 & Weight loss $(\%)$ & AOAC - 930.15(2000) & {$[35]$} \\
\hline 3 & Bulk density $(\mathrm{g} / \mathrm{mL})$ & ASTM D7454 & {$[36]$}
\end{tabular}

\begin{tabular}{llll}
\hline 4 & Ash content (\%) & AOAC -942.05PA(2000) & {$[35]$} \\
\hline 5 & Oil content (\%) & AOAC - 999.02(1999) & {$[37]$} \\
\hline 6 & Moisture content (\%) & AOAC (2007) & {$[38]$} \\
\hline 7 & Protein (\%) & AOAC- 920.53 (1995) & {$[39]$}
\end{tabular}

AOAC: Association of analytical chemistry, ASTM: American standard of testing materials

\subsubsection{Instrumental techniques for gastropod shell conchiolin analysis}

The instrumental analyses were conducted on the extracted coagulant (GSC) to ascertain some major qualitative and quantitative properties. The Fourier-transform infrared spectroscopy (FTIR) was conducted using Alpha-P spectrometers (Bruker Optics, Bryanston, South Africa) , X-ray Diffraction (XRD) was conducted using Bruker Apex-2 Duo single-crystal X-ray diffractometer, differential scanning calorimetric (DSC) pattern and Thermo-gravimetric analysis (TGA) were obtained using Q200 differential scanning calorimeter and TGA Q500 TA (both from TA instruments, Delaware) respectively. The scanning electron microscopic analysis (SEM) was conducted using ZEISS Merlin FE SEM, Germany.

\subsection{Coagulation-flocculation test}

The coagulation - flocculation studies considered the influence of different process variables $(\mathrm{pH}$, coagulant dosage, time, and temperature) on turbidity reduction via one-factor at a time (OFAT) method. The experimental design matrix was obtained using response surface design, while the optimal coagulation-flocculation conditions were established via ANN-GA.

\subsubsection{Coagulation-flocculation mechanism of gastropod shell conchiolin}

Bio-coagulation mechanism followed the actual mechanism of coagulation-flocculation process. It involves interaction between the negatively charged suspended particles and the positively charged coagulant particles [29]. This interaction follows four different mechanisms from the fast stirring (coagulation stage) stage to the floc sedimentation stage. Introduction of Gastropod shell conchiolin into the wastewater sample brings about double layer formation and compression, which in turns result to charge neutralization via charge-charge Columbic attraction [30]. This mechanism leads to destabilization of the stable colloidal particles resulting to formation of micro-flocs during the fast stirring 
stage. Within this period, there are net positive and negative charges from the adsorption of the colloidal particles onto the coagulants creating charged loops and tails for further interactions. These two mechanisms govern the coagulation stage of the process. Further slow stirring stage (flocculation stage) lead to inter-particle bridging and non-selective aggregation of more particles onto the available charged sites. The latter is known as sweep flocculation. Furthermore, particles are enmeshed as the flocs aggregate and gain weight. The flocs settle out by gravity leaving behind a clarified bulk of treated water $[20,25]$.

\subsubsection{Effect of coagulant dosage variation}

The initial $\mathrm{pH}$ and turbidity of the paint wastewater were measured at room temperature using thermoorion420A+ pH meter and MC-WZS-185 turbidity meter, respectively. $1000 \mathrm{~mL}$ of the paint effluent contained in six different $1000 \mathrm{~mL}$ beakers (gg-17, $10 \mathrm{~cm}$ in diameter) were dosed with $0.5,1,2,3,4$ and $5 \mathrm{~g}$ of gastropod shell conchiolin (GSC). The mixtures (paint effluent and GSC) were subjected to rapid mixing at $250 \mathrm{rpm}$ (velocity gradient $(G)=310 \mathrm{sec}^{-1}$ ) for 2 min, followed by slow mixing at $30 \mathrm{rpm}(\mathrm{G}=22$ $\mathrm{sec}^{-1}$ ) for 20 min using magnetic stirrer. Afterwards, the treated effluent was allowed to settle for 30 min. During the settling period, $20 \mathrm{~mL}$ of the supernatant was pipetted into the curvet of the turbidity meter for turbidity measurement at time intervals of $0,3,5,10,15,20,25$ and 30 minutes and readings were recorded in NTU. The residual turbidities recorded in NTU were converted to $\mathrm{mg} / \mathrm{L}$ by multiplying NTU by 2.35 as described by Menkiti et al [16]. Where, 2.35 is a factor for converting turbidity (NTU) to $\mathrm{mg} / \mathrm{L}$.

\subsubsection{Effect of pH variation}

The best coagulant dosage obtained from subsection 2.2.2 was used for the evaluation of $\mathrm{pH}$ effect. Equal quantities of the already established coagulant dosage were dosed into 6 different beakers with each containing $1000 \mathrm{~mL}$ of paint wastewater sample. The $\mathrm{pH}$ of the paint wastewater samples were adjusted to $2,4,6,8$ and 10 using $0.1 \mathrm{M} \mathrm{H}_{2} \mathrm{SO}_{4}$ and $0.1 \mathrm{M} \mathrm{NaOH}$ before dosing of the coagulant. 2 min of fast $(250 \mathrm{rpm})$ stirring, followed by $20 \mathrm{~min}(30 \mathrm{rpm})$ of slow stirring periods were performed on each of the mixtures. Thereafter, the residual turbidities were measured using turbidity meter within the settling period of $35 \mathrm{~min}$ at intervals of $3,5,10,15,20,25,30$ and $35 \mathrm{~min}$.

\subsubsection{Effect of temperature variation}

A set of Jar tests were carried out using the values of dosage and $\mathrm{pH}$ already determined in subsections 2.2.2 - 2.2.3. The temperature of the solution was adjusted to 25,35 and $45^{\circ} \mathrm{C}$ using magnetic stirrer, fitted with hot plate $\left(0-100^{\circ} \mathrm{C}\right)$ (B.Bran Scientific model). $2 \mathrm{~min}$ fast stirring at $250 \mathrm{rpm}$ followed by $20 \mathrm{~min}$ slow stirring at $30 \mathrm{rpm}$ were performed on each mixture. The residual turbidity was measured and recorded after the flocculation period, between $0-35 \mathrm{~min}$ for every $5 \mathrm{~min}$ intervals.

\subsubsection{Evaluation of comparative performance of alum and gastropod shell conchiolin}


Comparative jar tests were conducted at the observed best dosage and $\mathrm{pH}$ using GSC and alum. Two sets of 6 different beakers ( $1000 \mathrm{~mL}$ each) containing $1000 \mathrm{~mL}$ of paint wastewater were used. Equal grams of the GSC and alum $(0.5 \mathrm{~g}-5 \mathrm{~g})$ were introduced into the paint wastewater samples at the effluent's initial pH (7.89). After 2 min fast stirring at $250 \mathrm{rpm}$ and $20 \mathrm{~min}$ slow stirring at $30 \mathrm{rpm}$, the resultant mixture was allowed to settle for $30 \mathrm{~min}$. The residual turbidities were measured and recorded between $0-35 \mathrm{~min}$ at every $5 \mathrm{~min}$ intervals.

\subsection{Artificial neural network response prediction and optimization}

ANN system was used for response prediction, while Genetic algorithm was used for process optimization. The proposed route for ANN response prediction and GA optimization is illustrated in Figure 2.

Experimental design matrix was raised using central composite design (CCD) on response surface methodology (RSM) environment via design expert 12. Three factors (coagulant dosage (1-5g), time (5$30 \mathrm{~min})$ and temperature $\left(25-45^{\circ} \mathrm{C}\right)$ and a response variable (turbidity removal efficiency) were considered as input and output variables, respectively. The design matrix generated (Table 3) was used for the actual jar test experiment. According to process route in Figure 2, the result of the experiment were used for ANN network modeling, training, testing and validation producing output variables (predicted responses) according to the run order in Table 1. The predicted responses were compared with the experimental result and optimized using genetic algorithm. 
Table 3: Design Matrix for PW-GSC) (paint wastewater-gastropod shell conchiolin) coagulation

\begin{tabular}{|c|c|c|c|c|}
\hline Std & Run & Dosage(g/l) & Time(min) & Temp(K) \\
\hline 20 & 1 & 3.25 & 20 & 308 \\
\hline 4 & 2 & 5 & 30 & 298 \\
\hline 8 & 3 & 5 & 30 & 318 \\
\hline 17 & 4 & 3.25 & 20 & 308 \\
\hline 15 & 5 & 3.25 & 20 & 308 \\
\hline 18 & 6 & 3.25 & 20 & 308 \\
\hline 5 & 7 & 1.5 & 10 & 318 \\
\hline 13 & 8 & 3.25 & 20 & 291 \\
\hline 19 & 9 & 3.25 & 20 & 308 \\
\hline 10 & 10 & 6.19 & 20 & 308 \\
\hline 9 & 11 & 0.31 & 20 & 308 \\
\hline 3 & 12 & 1.5 & 30 & 298 \\
\hline 11 & 13 & 3.25 & 30 & 308 \\
\hline 16 & 14 & 3.25 & 20 & 308 \\
\hline 6 & 15 & 5 & 10 & 318 \\
\hline 1 & 16 & 1.5 & 10 & 298 \\
\hline 12 & 17 & 3.25 & 37 & 308 \\
\hline 7 & 18 & 1.5 & 30 & 318 \\
\hline 14 & 19 & 3.25 & 20 & 324 \\
\hline 2 & 20 & 5 & 10 & 298 \\
\hline 12 & 19 & 3.25 & 37 & 308 \\
\hline 9 & 20 & 0.31 & 20 & 308 \\
\hline
\end{tabular}

Response prediction model was developed via back propagation neural network (BP) method in ANNMATLAB 12 environment. BP algorithm constitutes of input, hidden layer and output with neurons as the basic processing unit. Prediction model is developed by connecting the different layers of data with appropriate weights $(w)$ and biases (b) [30]. Figure 3, shows the ANN neural architecture for the inputhidden-output interaction. 
In Back Propagation method, the output of neurons in input layers serve as input to the hidden layer, while the output of the hidden layers serves as input for output layer that finally gives desired output [40]. In this present study, the design matrix with the experimental generated responses (Table 4) were used to develop a robust network structure. Learning choice of $70-20-10 \%$ was adopted for network training, testing and validation.

\section{Table 4: Experimental design matrix and responses}

\begin{tabular}{|c|c|c|c|c|}
\hline Run & Dosages $(\mathrm{g})$ & Time(min) & Temp (K) & Removal Efficiency (\%) \\
\hline 1 & 3.25 & 20.00 & 308.00 & 93.501 \\
\hline 2 & 5.00 & 30.00 & 298.00 & 93.655 \\
\hline 3 & 5.00 & 30.00 & 318.00 & 98.524 \\
\hline 4 & 3.25 & 20.00 & 308.00 & 96.0102 \\
\hline 5 & 3.25 & 20.00 & 308.00 & 94.9032 \\
\hline 6 & 3.25 & 20.00 & 308.00 & 93.9932 \\
\hline 7 & 1.50 & 10.00 & 318.00 & 72.9414 \\
\hline 8 & 3.25 & 20.00 & 291.18 & 93.1599 \\
\hline 9 & 3.25 & 20.00 & 308.00 & 95.0032 \\
\hline 10 & 6.19 & 20.00 & 308.00 & 95.4339 \\
\hline 11 & 0.31 & 20.00 & 308.00 & 58.8966 \\
\hline 12 & 1.50 & 30.00 & 298.00 & 79.6962 \\
\hline 13 & 3.25 & 3.18 & 308.00 & 82.0144 \\
\hline 14 & 3.25 & 20.00 & 308.00 & 95.9032 \\
\hline 15 & 5.00 & 10.00 & 318.00 & 97.1728 \\
\hline 16 & 1.50 & 10.00 & 298.00 & 71.0832 \\
\hline 17 & 3.25 & 36.82 & 308.00 & 95.8991 \\
\hline 18 & 1.50 & 30.00 & 318.00 & 83.5544 \\
\hline 19 & 3.25 & 20.00 & 324.82 & 90.7346 \\
\hline 20 & 5.00 & 10.00 & 298.00 & 91.5981 \\
\hline 19 & 3.25 & 36.82 & 308.00 & 83.2192 \\
\hline 20 & 0.31 & 20.00 & 308.00 & 39.9568 \\
\hline
\end{tabular}

The network node activation was done using sigmoid transfer function (STF) as shown in Equation 1. 
$\mathrm{STF}=\frac{1}{1+\mathrm{e}^{-\mathrm{x}}}$

(1) [41]

The network training was conducted using Levenberg-Marquardt learning algorithm (Trainlm) and the output function followed Purelin transfer function. ANN-Genetic algorithm was used for process optimization.

\section{Result And Discussion}

\subsection{Characterization of Paint wastewater}

The results obtained from the characterization of the paint wastewater sample are presented in Table 5. From Table 5, it can be observed that the paint wastewater has high content of TSS and TDS of 2685 $\mathrm{mg} / \mathrm{L}$ and $1318 \mathrm{mg} / \mathrm{L}$, respectively as against the NERS (National effluent regulatory standard) of 705 $\mathrm{mg} / \mathrm{L}$ and $1200 \mathrm{mg} / \mathrm{L}[16]$. The high TSS and TDS observed in paint wastewater indicate that the wastewater contains high particle load. Comparing the total solid content with NERS, it was observed that the paint wastewater sample contains $2098 \mathrm{mg} / \mathrm{L}$ in excess of the NERS. Hence it can be inferred that the paint wastewater is highly turbid and cannot be discharged to the environment without treatment.

Table 5: Wastewater Analysis

\begin{tabular}{lcccc}
\hline \multicolumn{4}{c}{ Paint wastewater quality } & NERS \\
\hline TS (mg/L) & 4003 & 1905 & \\
\hline TSS (mg/L) & & 2685 & & 705 \\
\hline TDS (mg/L) & 1318 & & 1200 & \\
\hline $\mathrm{pH}$ & & 7.89 & & $7-8$ \\
\hline
\end{tabular}

TS: Total solid, TDS: Total dissolved solid, TSS: Total suspended solid

\subsection{Characterization of GSF and GSC}

\subsubsection{The Proximate characterization of GSF}

Proximate analysis was carried out on the gastropod shell flour (GSF) to determine the proximate compositions such as crude protein, oil content, ash content, bulk density and moisture content using standard methods cited in Table 2. The result of the proximate analysis shows that GSF contains high quantity of crude protein (42\%). Based on the protein content observed, it could be inferred that GSF is an efficient precursor for the extraction of raw protein (conchiolin) that can be used for wastewater treatment. The oil content was found to be $7.4 \%$. Oil content of this percentage ( $\nabla 10 \%)$ would have negligible inhibitory effect on the deprotenization process [16]. The total yield of $86 \%$ was obtained 
indicating $14 \%$ weight loss which could be attributed to the volatile components present in the GSF sample. The bulk density of $0.33 \mathrm{~g} / \mathrm{mL}$ indicates that GSF is extremely aeratable. In addition, the ash content of $10 \%$ shows that the flour is rich in minerals while negligible moisture content of $8.6 \%$ was obtained.

\subsubsection{Elemental Analysis}

Elemental analysis was carried out on both the GSF and the GSC to evaluate their qualitative and quantitative composition. The results obtained are reported in Table 6. From the results, it could be seen that GSF has high content of calcium. Calcium content of $70 \%$ was recorded which supports the claim that GSF contains between 70-98 \% calcium [30]. This high calcium content is justified since the animal uses it for body replenishment [30]. High content of oxygen (26.36) in GSF can be traced to the presence of protein in the shell [16]. The presence of carbon (7.47\%) is attributed to the carbonaceous nature of GSF. From the elemental characterization of GSC (Table 6), it could be observed that more elements were present ( $\mathrm{Na}, \mathrm{Mg}, \mathrm{Al}$. P, Si, Cl, K) which were not in GSF. The additional elements and the observed $20.7 \%$ reduction in calcium content in GSC can be attributed to the effect of GSF reaction with the extraction solution. The oxygen content of both GSF and GSC were observed to be approximately the same (26.36 and $25.94 \%$ ), indicating that the deproteinization process was effective.

\begin{tabular}{lcc}
\multicolumn{3}{l}{ Table 6: Chemical } \\
\hline Elements & GSF & GSC \\
\hline $\mathrm{C}$ & 7.47 & 6.53 \\
\hline $\mathrm{Na}$ & & 21.7 \\
\hline $\mathrm{Mg}$ & - & 0.23 \\
\hline $\mathrm{Al}$ & & 0.24 \\
\hline $\mathrm{P}$ & - & \\
\hline $\mathrm{Si}$ & - & 0.14 \\
\hline $\mathrm{Cl}$ & - & 0.21 \\
\hline $\mathrm{K}$ & - & 0.19 \\
\hline $\mathrm{Ca}$ & 65.8 & 45.1 \\
\hline $\mathrm{O}$ & 26.36 & 25.94 \\
\hline
\end{tabular}

\subsection{Instrumental analysis for GSC}

\subsubsection{FTIR Studies}

The infrared spectra of GSF and GSC shown in Figures 4 and 5 revealed peaks representing different functional groups. It is observable that the spectra fall within the mid infrared region $\left(4000-400 \mathrm{~cm}^{-}\right.$ 
${ }^{1}$ ). Figures 4 and 5 were analyzed and compared with the existing FTIR data base (FDM NIST08 Mass Spectral Library) $[16,30]$. From the regions of absorbance, some functional groups were observed. The FTIR spectrum pattern for GSF (Fig. 4) exhibits 20 discernable peaks at frequency of $4000-700 \mathrm{~cm}^{-1}$, threshold of 0.44; while in that of GSC, 16 discernable peaks were observed (Figure 5) between the frequencies of $4000-600 \mathrm{~cm}^{-1}$. The principal peaks in the spectrum were detected at $3648 \mathrm{~cm}^{-1}, 3627$ $\mathrm{cm}^{-1}, 3580 \mathrm{~cm}^{-1}, 3291 \mathrm{~cm}^{-1}, 1457 \mathrm{~cm}^{-1}, 1082 \mathrm{~cm}^{-1}, 1017 \mathrm{~cm}^{-1}, 844 \mathrm{~cm}^{-1}, 712 \mathrm{~cm}^{-1}$ and $700 \mathrm{~cm}^{-1}$ (Figure 4). The highest peak at $1457 \mathrm{~cm}^{-1}$ was observed within the FTIR fingerprint region. The presence of aromatic group was exhibited by the broad bands in the regions above $3000 \mathrm{~cm}^{-1}\left(3281 \mathrm{~cm}^{-1}, 3580 \mathrm{~cm}^{-1}, 3627 \mathrm{~cm}^{-}\right.$ 1 and $3648 \mathrm{~cm}^{-1}$ ). The peak at $2919 \mathrm{~cm}^{-1}$ shows the presence of asymmetric methyl group, peaks at $1082 \mathrm{~cm}^{-1}$ and $1017 \mathrm{~cm}^{-1}$ depict the aliphatic $\mathrm{C}-\mathrm{N}$ stretching while peaks at $844 \mathrm{~cm}^{-1}, 712 \mathrm{~cm}^{-1}$ and 700 $\mathrm{cm}^{-1}$ show the presence of phosphorous compound of $\mathrm{P}-\mathrm{F}$ stretching.

Figure 5 shows distinct peaks for GSC. The reduction in number of peaks when compared with Figure 4 shows that some functional groups were removed during the extraction process. A shift in peaks orientation can also be observed from the X-H stretching region to fingerprint region. In Figure 4, 14 discernable peaks were found within the X-H stretching region, while 2 peaks were observed within the same region in Figure 5. The shift can be associated with longitudinal acoustical modes (accordion modes) resulting from molecular distortion and bond breaking during the extraction $[30,41]$. The stunted broad band between $4000-3000 \mathrm{~cm}^{-1}$ in Figure 4 was replaced with very broad strong band (in Figure 5) at $3645 \mathrm{~cm}^{-1}$ and $3356 \mathrm{~cm}^{-1}$ indicating $\mathrm{Si}-\mathrm{OH}$ stretching which can be confused with those of $\mathrm{O}-\mathrm{H}$ frequencies. The highest peak on Figure 5 was observed at $1456 \mathrm{~cm}^{-1}$, with threshold frequency of 1.08 . The sharp distinct peak at $1456 \mathrm{~cm}^{-1}$ can be connected to methylene scissoring in alkane group. Also, discernable peaks were recorded at the upper wave number end, the peaks at $699 \mathrm{~cm}^{-1}$, and $648 \mathrm{~cm}^{-1}$ are linked to $\mathrm{C}-\mathrm{H}$ bending of alkyne group. The peak observed at $1082 \mathrm{~cm}^{-1}$ is an indication of $\mathrm{C}-\mathrm{O}$ stretching band (Ethers) due to the $\mathrm{C}-\mathrm{O}-\mathrm{C}$ linkage. $\mathrm{C}-\mathrm{O}$ stretching band can be observed near $1150 \mathrm{~cm}^{-1}\left(1154 \mathrm{~cm}^{-}\right.$ $\left.{ }^{1}\right)$, indicating the presence of Anhydrides. A broad N-H wagging band also appears at $750-650 \mathrm{~cm}^{-1}$ indicating the presence of secondary amine which can be linked to the protein constituent of GSC.

\subsubsection{X-Ray diffraction analysis of GSF and GSC}

The X-ray diffraction spectrum of GSF and GSC are shown in Figures 6 and 7. It can be observed that Figure 6 clearly shows well recognized intense peaks. This spectrum is an X-Y plot of $2 \theta$ vs X-ray count (intensity). Fourteen clear peaks assigned due to their different reflections and planes were observed at scattering angles of $2 \theta=26.5^{\circ}, 27.8^{\circ}, 31.5^{\circ}, 33^{\circ}, 36^{\circ}, 37^{\circ}, 38^{\circ}, 42^{\circ}, 43^{\circ}, 46^{\circ}, 48^{\circ}, 51^{\circ}, 52.5^{\circ}$, $53^{\circ}$. From the nature of these peaks in Fig. 6 , a symmetric organized crystalline structure can be inferred. The spectrum for GSC presented in Figure. 7 shows a less coherent arrangement of fourteen distinct peaks when compared with Figure. 5. The peaks can be observed at scattering angles of $2 \theta=$ $31.5^{\circ}, 34^{\circ}, 35^{\circ}, 36.5^{\circ}, 38^{\circ}, 42^{\circ}, 43^{\circ}, 45^{\circ}, 46^{\circ}, 48^{\circ}, 51^{\circ}$ (Fig. 7). The asymmetric peaks arrangement in Figure.7 indicates a semi-crystalline molecular arrangement. This type of molecular arrangement infers 
that GSC is an isotropic amorphous compound [42]. Comparison between Figures 6 and 7 based on the nature of peaks show that GSF is more structurally stable than GSC.

\subsubsection{DSC /TGA Analysis for GSF and GSC}

The DSC and TGA representation of GSF and GSC obtained are shown below in Figure 8 ( $a, b, c$ and d), respectively. The Figure 8 ( $a$ and $b$ ) (the DSC profiles of GSF and GSC) represent application of DSC for the characterization of the phase transition that occurred in GSF and GSC over the temperature ranges of $38-298^{\circ} \mathrm{C}$ and $45-300^{\circ} \mathrm{C}$, respectively. The transition enthalpies of $23.091 \mathrm{~kJ} / \mathrm{mol}$ and $11.620 \mathrm{~kJ} / \mathrm{mol}$, respectively were obtained. The thermal activation energy $(\Delta \mathrm{E})$ was evaluated through TGA to be 25.86 $\mathrm{kJ} / \mathrm{mol}$ and $45.928 \mathrm{~kJ} / \mathrm{mol}$ for GSF and GSC, respectively using method described by Menkiti and Ejimofor, [30].

GSF produced sharp transition in the temperature range of $62.5-81^{\circ} \mathrm{C}$, while GSC produced its sharp transition between $49-52^{\circ} \mathrm{C}$. These behaviors could be linked to spontaneous densification during thermal treatment of the samples. The densification of the aggregated mass took place at temperatures of $100-150^{\circ} \mathrm{C}$ for GSF (Figure 8a) and $115-175^{\circ} \mathrm{C}$ for GSC (Figure 8b). The glass transition temperatures were observed between $37.5-42{ }^{\circ} \mathrm{C}$ for GSF and $48-52{ }^{\circ} \mathrm{C}$ for GSC. Furthermore, it was observed that GSC has higher glass transition temperature than GSF; this implies that GSC can withstand more operational increase in temperature than GSF without being denatured [30,32]. Within the glass transition stage, the onset, midpoint and offset transition points can be observed at the temperatures of $37.5^{\circ} \mathrm{C}, 39.3^{\circ} \mathrm{C}$ and $42^{\circ} \mathrm{C}$ for GSF, and $48^{\circ} \mathrm{C}, 50^{\circ} \mathrm{C}$ and $52^{\circ} \mathrm{C}$ for GSC, respectively. A clear observation of the DSC graphs demonstrated a situation in which the heat flow discs indicate exothermic nature for both GSF and GSC.

Figure 8 (c and d), shows the thermal-gravimetric analysis (TGA) profiles of the two samples (GSF and GSC). Graphically, the Figures represent variation in weight with respect to temperature. The final residual masses for GSF and

GSC estimated based on weight loss with respect to temperature are $5.72218 \mathrm{mg}$ and $1.974 \mathrm{mg}$, representing $89.2 \%$ and $74.9 \%$ of the original weights of GSF $(6.415 \mathrm{mg})$ and GSC $(2.634 \mathrm{mg})$ sample, respectively. The initial weight loss observed in Figure 8 ( $c$ and d) could be linked to internal moisture content and gaseous loss from the matrix molecules [30]. The second phase weight loss may be as a result of decomposition in the samples. The results conclusively suggested thermal operational stability of the GSF and GSC as indicated by significant final residue percentage of $89.2 \%$ and $74.9 \%$ for GSF and GSC, respectively.

\subsubsection{SEM characterization of GSC}

The analysis of the external morphology (texture) of GSC was obtained via scanning electron microscopic evaluation (SEM). The SEM image obtained is presented in Figure 9. A compact structure with tiny pores and small stick littered external morphology is observable at 100um. It shows a good 
characteristic for an effective coagulant. Coagulants with reduced particle sizes and increased surface porosity would provide a better platform for adsorption of fine suspended particles.

\subsection{Effect of process variables via OFAT}

Conventional application of one factor at a time (OFAT) method evaluates the impact of one variable within a process by holding other variables at constant level [43].

\subsubsection{Effect of pH on coagulation efficiency}

The effect of $\mathrm{pH}$ on the coagulation system under consideration is illustrated in Figure 10. The $\mathrm{pH}$ of the solution is a critical parameter in most treatment processes [40,41]. It affects the surface charge of the coagulant [44]. From Figure 10, at constant GSC dosage of $5 \mathrm{~g}$ and $30 \mathrm{~min}$ settling time, two regions are notable, a region where the removal efficiency was at maximum and a region where it was at minimum. The removal efficiency was highest at $\mathrm{pH}$ of 4 . A similar result was reported by Zhao et al.[45] on the effect of $\mathrm{pH}$ on coagulation, using ferric based coagulant in yellow river water treatment. Also, Sun et al [46] reported best removal efficiency within the same acidic region. The high removal efficiency within 2-4 could be attributed to progressive protonation of the coagulation system as GSC releases positive charges which progressively conjugated with the available negative species towards equilibrium. The region between the $\mathrm{pH}$ of 5-8 represents a region of progressive decline in particle neutralization and floc formation. This decline can be attributed to decline in GSC solubility within the system as a result of change in $\mathrm{pH}$ from strong acidity to alkalinity. At $\mathrm{pH}$ of 8 , minimum particle removal efficiency (12\%) was observed. This $\mathrm{pH}$ of minimum particle removal may be referred to as the point of zero charge for GSC. At this point ( $\mathrm{pH}$ of 8 ), the surface charges of the coagulant available for charge neutralization are negligible. After the point of zero charge of GSC, the coagulation environment becomes more alkaline. At this stage, GSC is less soluble. However, the surface charge is not completely zero, which resulted in slight increase in removal efficiency at $\mathrm{pH}$ of 10. This result (subsection 3.4.1) suggests that GSC is more effective in acidic environment.

\subsubsection{Effect of coagulant dosage on coagulation efficiency}

Variation in turbidity removal efficiency with GSC dosage at constant time (30min) and best $\mathrm{pH}$ (4) adopted from section 3.31 is presented in Figure 10. Turbidity removal efficiency was found to increase from minimum to the maximum with increase in GSC dosage before a sharp decline (Figure 11). This trend (progressive increase of removal efficiency to maximum) could be as a result of increase on the availability of positively charged particles provided by the GSC for destabilization of the negatively charged suspended particles. A sharp decline in particles removal efficiency from $4 \mathrm{~g} / \mathrm{L}$ could be attributed to excess coagulant concentration, which may have resulted in re-turbidization of the effluent [16]. Re-turbidization results from charge reversal due to increased net concentration of positively charged coagulant particles $[16,17]$. The curved profile of Figure 11 shows the effect of individual coagulant dosage on the particles decontamination process. The minimum particles decontamination 
efficiency $(18 \%)$ was observed at the coagulant dosage of $0.5 \mathrm{~g} / \mathrm{L}$, while the highest particles removal efficiency $(98.1 \%)$ was observed at $4 \mathrm{~g} / \mathrm{L}$ of GSC.

\subsubsection{Effect of settling time on coagulation efficiency at different temperatures}

The variations in removal efficiency with time at different temperatures are shown in Figure 12. Figure 12 shows that removal efficiency increased with increase in settling time till equilibrium was attained. At equilibrium stage, $93.1 \%, 93.9 \%$, and $98.7 \%$ reduction in turbidity was achieved at $25^{\circ} \mathrm{C}, 35^{\circ} \mathrm{C}$ and $45^{\circ} \mathrm{C}$, respectively. The equilibrium stages were observed at $20 \mathrm{~min}$ after which there was no more significant reduction in turbidity of the treated paint wastewater samples. Hence, most of the flocs settled between 020 minutes. 20 minutes equilibrium time is desirable for peri-kinetic coagulation. In addition, it was observed that increase in temperature increased the coagulation efficiency as well. This increase in efficiency resulted from increased particle excitation due to increase in particles kinetic energy [30]. Also increase in temperature lowers the viscosity of PW. Hence, the particles movement becomes more rapid leading to more effective particle collision and floc formation. Highest efficiency of $93.16 \%$ was observed at $25^{\circ} \mathrm{C}$. Slight increase was observed (from $93.16 \%$ to $95.433 \%$ ) as the temperature increased to $35^{\circ} \mathrm{C}$. Furthermore, the removal efficiency increased to $98.224 \%$ as the temperature was increased to $45^{\circ} \mathrm{C}$.

\subsubsection{Characteristics of the treated water after coagulation}

After the coagulation experiment, the treat wastewater had TS of $791 \pm 0.03 \mathrm{mg} / \mathrm{l}$, TSS of $275 \pm 0.024$, TDS of $516 \pm 0.016$ and $\mathrm{pH}$ of 7.2 as against the national discharge limit of $1905 \mathrm{mg} / \mathrm{l}, 705 \mathrm{mg} / \mathrm{l}, 1200$ and $\mathrm{pH}$ $7-8$. Hence, it can be inferred that the treated wastewater can be discharged into the environment without adverse effect.

\subsection{Response prediction and optimization using ANN and GA}

Figure 13 shows the artificial neural network system histogram. ANN system histogram represents the error that approaches the network mean square error (MSE). It shows that approximately 12 instances were used for training, 5 for testing while the remaining was used for validation. The zero error line reveals -6.202 errors in 20 bins. The error shows the extent of correlation between the target and prediction. Hence, the negative sign show that predictions are higher than target. However, error of values $<10$ indicates relatively good correlation between the target and the predicted responses. The network progress was monitored based on validation error

Network training was terminated at increase in validation error. The root mean squared error (RMSE) network performance curve shown in Figure 14 illustrates the plot of the observed RMSE against the epochs. In Figure 14, three different curves were built for training, testing and validation. The dotted line shows the best possible network conditions for training, testing and network validation based on the root mean squared error. The best validation performance was obtained at RMSE of 7.7084 at epoch 5 . The validation performance suggests that after the fifth iterations (epoch 5), the network attained its best learning stage at the lowest possible RMSE (7.7084). Also, the RMSE measures the correlation between 
the target and ANN predicted responses. The best RMSE $<10$ infers relative high correlation between the output (ANN predicted turbidity removal) and the target (Experimental turbidity removal). In addition, the network capacity to predict significant output was illustrated by the training state plot (Figure 15).

The network gradient of $1.9506^{-11}$ (loss function) was computed to illustrate the error contribution of each neuron at 5 epochs (Figure 15). Lower error is better [16]. The gradient was very much less than unity (1.9506e-11), it indicates that the error contribution of each neuron within the 5 epochs is minimal. Momentum gain $\mathrm{(Mu})$ is the training gains and its value is expected to be less than one [16] "Mu" closer to zero shows high capacity of the trained network in making significant response prediction. In support of the RMSE and the training output result in network accuracy, the training, testing, validation and the overall network correlation coefficient $\left(R^{2}\right)$ of $0.97,0.99,0.97$ and 0.93 were obtained from the performance plot of training, testing, validation and All (overall network performance) as shown in Figure 16.

Based on the $\mathrm{R}^{2}$-values, $(0.97,0.99,0.97$ and 0.93$)$, it is inferred that the network has significant fitting performances in all the stages (training, testing and validation). The overall network performance equation (Equation 2) shows the overall relationship between the target and the output. The network output (predicted Turbidity removal efficiency (\%)) obtained from software iteration within the hidden layers (Table not shown) was compared with the target (experimental removal efficiency) based on the correlation coefficient.

Output $=0.73 *$ target +24

A strong correlation is always inferred for $\mathrm{R}^{2}$ value $\geq 0.7$ [30].Correlation coefficient of 0.92 and mean average percentage error (MAV.PE) of 0.36 were obtained (Low average percentage error (close to zero) is desired because it indicates insignificant error between the experimental and predicted data). From the present comparison very strong correlation between the two data sets (output and target) can be inferred. In support of this judgment based on $\mathrm{R}^{2}$ values and the MAV.PE, Figure 17 shows the plot of output and target with respect to experimental run order. Visual assessment of Figure 17 gave credence to the result obtained in Figure 14. The slight deviations observed at run 14 and 20 (Figure 17) may be attributed to data approximation during generation of hidden hyper-parameters for response prediction.

The optimization of turbidity removal efficiency based on ANN predicted overall model equation (Equation 2) was carried out through genetic algorithm (GA). This metaheuristic Al approach provides an approximate optimal by evaluating sets of chromosomes created via GA operational environment. The target of the response optimization (set at $99.999 \%$ ) is subject to the total weight such that the optimal response is as higher as possible and not exceeding the maximum weight $[16,30]$ which is $100 \%$ for the present study. The weight of the data set was scaled into a continuous interval using fuzzy C-means. Population data in Table 4 applied as the initial population to Equation 2 (transfer function relating the weight to target) passed through reoccurring data crossover and mutation before termination. The outcome of the GA operation based on the convergence of optimal solutions show that the optimal 
turbidity removal of $98 \%$ can be accomplished at GSC dosage, time and temperature of $4 \mathrm{~g}, 20 \mathrm{~min}$ and $45^{\circ} \mathrm{C}$, respectively. This optimal response was selected from a queue of 20 local optima conditions (not shown) returned at termination of GA operation.

\section{Conclusion}

The following conclusion can be drawn from the study of turbidity removal from paint wastewater using conchiolin via hybridization of response surface methodology and artificial neural network-genetic algorithm.

- Gastropod shell conchiolin sourced from waste agricultural residue contains active protein and was effective in turbidity removal from paint wastewater.

- Turbidity removal efficiency was influenced by Gastropod shell conchiolin dosage, $\mathrm{pH}$, time and temperature

- Response surface design responses were successfully used as input for artificial neural network model prediction and genetic algorithm optimization

- Genetic algorithm optimization suggested that $98.6 \%$ turbidity removal can be achieved at $4 \mathrm{~g}$ gastropod shell conchiolin, $20 \mathrm{~min}$ and $45^{\circ} \mathrm{C}$.

- The optimal values obtained both for the variables and the responses are good conditions for perikinetic coagulation.

- Gastropod shell (s) is/are no more waste, if properly harnessed can be used as coagulant precursor and can be very effective in wastewater management.

\section{Declarations}

\section{Acknowledgement}

The authors wish to thank in a special way, Chemical Engineering Department, Nnamdi Azikiwe University, Awka, Anambra State for making their laboratory and equipment available for the research work. This research did not receive any specific grant from funding agencies in the public, commercial, or not-for-profit sectors. The authors funded the research.

\section{References}

1. Abd-Elaty, I., Kuriqi, A., \& Shahawy, A. E. (2021). Environmental rethinking of wastewater drains to manage environmental pollution and alleviate water scarcity. Natural Hazards, 1-28.

2. Subramonian, W., Wu, T. Y., \& Chai, S. P. (2015). An application of response surface methodology for optimizing coagulation process of raw industrial effluent using Cassia obtusifolia seed gum together with alum. Industrial Crops and Products, 70, 107-115 
3. Zhang, L., Zhu, X., Wang, Z., Zhang, J., Liu, X., \& Zhao, Y. (2021). Improved speciation profiles and estimation methodology for VOCs emissions: A case study in two chemical plants in eastern China. Environmental Pollution, 291, 118192.

4. Menkiti, M. C., Okoani, A. O., \& Ejimofor, M. I. (2018). Adsorptive study of coagulation treatment of paint wastewater using novel Brachystegia eurycoma extract. Applied Water Science, 8(6), 1-15.

5. Igbinosa, E. O., \& Okoh, A. I. (2009). Impact of discharge wastewater effluents on the physicochemical qualities of a receiving watershed in a typical rural community. International Journal of Environmental Science \& Technology, 6(2), 175-182.

6. Osode, A. N., \& Okoh, A. I. (2009). Impact of discharged wastewater final effluent on the physicochemical qualities of a receiving watershed in a suburban community of the Eastern Cape Province. Clean-Soil, Air, Water, 37(12), 938-944.

7. Okoh, Anthony I., Emmanuel E. Odjadjare, Etinosa O. Igbinosa, and Augustina N. Osode. "Wastewater treatment plants as a source of microbial pathogens in receiving watersheds." African Journal of Biotechnology 6, no. 25 (2007).

8. Carlson, J. C., Anderson, J. C., Low, J. E., Cardinal, P., MacKenzie, S. D., Beattie, S. A., ... Hanson, M. L. (2013). Presence and hazards of nutrients and emerging organic micropollutants from sewage lagoon discharges into Dead Horse Creek, Manitoba, Canada. Science of the total environment, 445, 64-78.

9. Ejimofor, M. I., Ezemagu, I. G., \& Menkiti, M. C. (2021). Physiochemical, Instrumental and thermal characterization of the post coagulation sludge from paint industrial wastewater treatment. South African Journal of Chemical Engineering.

10. Augusto, P. A., Castelo-Grande, T., Vargas, D., Hernández, L., Merchán, L., Estevez, A. M., ... Barbosa, D. (2020). Water decontamination with magnetic particles by adsorption and chemical degradation. influence of the manufacturing parameters. Materials, 13(10), 2219.

11. Sharma, M., Joshi, M., Nigam, S., Shree, S., Avasthi, D. K., Adelung, R., ... Mishra, Y. K. (2019). ZnO tetrapods and activated carbon based hybrid composite: Adsorbents for enhanced decontamination of hexavalent chromium from aqueous solution. Chemical Engineering Journal, 358, 540-551.

12. Sadeddin, K., Naser, A., \& Firas, A. (2011). Removal of turbidity and suspended solids by electrocoagulation to improve feed water quality of reverse osmosis plant. Desalination, 268(1-3), 204-207.

13. Song, Z., Williams, C. J., \& Edyvean, R. G. J. (2000). Sedimentation of tannery wastewater. Water Research, 34(7), 2171-2176.

14. Jones, A. B., Dennison, W. C., \& Preston, N. P. (2001). Integrated treatment of shrimp effluent by sedimentation, oyster filtration and macroalgal absorption: a laboratory scale study. Aquaculture, 193(1-2), 155-178.

15. LIU, D. Y., \& ZHOU, J. (2004). Removing of microbe and sediment of soy sauce by ultra filtration [J]. Chinese Condiment, 4.

16. Ezemagu, I. G., Ejimofor, M. I., Menkiti, M. C., \& Nwobi-Okoye, C. C. (2021). Modeling and optimization of turbidity removal from produced water using response surface methodology and artificial neural 
network. South African Journal of Chemical Engineering, 35, 78-88.

17. Okey-Onyesolu, C. F., Onukwuli, O. D., Ejimofor, M. I., \& Okoye, C. C. (2020). Kinetics and mechanistic analysis of particles decontamination from abattoir wastewater (ABW) using novel Fish Bone Chitoprotein (FBC). Heliyon, 6(8), e04468.

18. Menkiti, M. C., Ezemagu, I. G., Nwoye, C. I., \& Ejimofor, M. I. (2016). Post-treatment sludge analyses and purification of paint effluent by coag-flocculation method. International Journal of Energy and Environmental Engineering, 7(1), 69-83.

19. Ejimofor, M. I., Ezemagu, I. G., \& Menkiti, M. C. (2021). RSM and ANN-GA modeling of colloidal particles removal from paint wastewater via coagulation method using modified Aguleri montmorillonite clay. Current Research in Green and Sustainable Chemistry, 100164.

20. EJIMOFOR, M. I., MENKITI, M. C., \& EZEMAGU, I. G. (2020). COMPARATIVE STUDIES ON REMOVAL OF TURBID-METRIC PARTICLES (TDSP) USING ANIMAL BASED CHITO-PROTEIN AND ALUMINIUM SULFATE ON PAINT WASTEWATER (PWW). Sigma: Journal of Engineering \& Natural Sciences/Mühendislik ve Fen Bilimleri Dergisi, 38(3).

21. Ejimofor, M. I., Menkiti, M. C., \& Ezemagu, I. G. (2021). Integrated Treatment of Paint Wastewater Using Helix Pometia Shell Coagulant and Sludge Conversion to Biogas: Process Thermodynamics and Biogas Energy Content. International Journal of Plant, Animal and Environmental Sciences, 11 , 391-422.

22. Bahrodin, M. B., Zaidi, N. S., Hussein, N., Sillanpää, M., Prasetyo, D. D., \& Syafiuddin, A. (2021). Recent advances on coagulation-based treatment of wastewater: Transition from chemical to natural coagulant. Current Pollution Reports, 1-13.

23. Cheng, W. P., Chi, F. H., Yu, R. F., \& Lee, Y. C. (2005). Using chitosan as a coagulant in recovery of organic matters from the mash and lauter wastewater of brewery. Journal of Polymers and the Environment, 13(4), 383-388.

24. Saravanan, J., Priyadharshini, D., Soundammal, A., Sudha, G., \& Suriyakala, K. (2017). Wastewater treatment using natural coagulants. SSRG International Journal of Civil Engineering, 4(3), 40-42.

25. Chi, F. H., \& Cheng, W. P. (2006). Use of chitosan as coagulant to treat wastewater from milk processing plant. Journal of Polymers and the Environment, 14(4), 411-417.

26. Ndabigengesere, A., \& Narasiah, K. S. (1998). Use of Moringa oleifera seeds as a primary coagulant in wastewater treatment. Environmental Technology, 19(8), 789-800.

27. Nwabanne, J. T., Oguegbu, O. O., \& Agu, C. M. (2018). Kinetics and performance of coagulation process using Mucuna seed shell for the treatment of paint wastewater. Journal of the Chinese Advanced Materials Society, 6(4), 738-754.

28. Ezemagu, I. G., Ejimofor, M. I., \& Menkiti, M. C. (2021). Instrumental and thermal characterization of the sludge generated after bio-coagulation treatment (GSABT) of petroleum produced water (PW). Results in Engineering, 9, 100187.

29. Babayemi, K. A. (2013). Coag-Flocculation Kinetics of Mucuna sloanei Seed for Phosphorus Removal from Waste Water. American Journal of Analytical Chemistry, 4(12), 732. 
30. Rao, D. H., Tagore, G. R. N., Janardhana, G. R., \&Kun, K. S. (2007). Development of optimized ANN model through Genetic Algorithm to predict the microstructural parameters of aluminum alloy castings. i-Manager's Journal on Future Engineering and Technology, 3(2), 55

31. Teixeira, R. C. A., \& Amaral, M. C. S. (2016). Caracterização físico-química de efluente deUma oficina de veículos ferroviários.

32. Clark, S. E., \& Pitt, R. (2008). Comparison of stormwater solids analytical methods for performance evaluation of manufactured treatment devices. Journal of Environmental Engineering, 134(4), 259264.

33. Ejimofor, M. I., Ezemagu, I. G., \& Menkiti, M. C. (2020). Biogas production using coagulation sludge obtained from paint wastewater decontamination: Characterization and anaerobic digestion kinetics. Current Research in Green and Sustainable Chemistry, 3, 100024.

34. Cheow, C. S., Norizah, M. S., Kyaw, Z. Y., \& Howell, N. K. (2007). Preparation and characterisation of gelatins from the skins of sin croaker (Johnius dussumieri) and shortfin scad (Decapterus macrosoma). Food chemistry, 101(1), 386-391.

35. Ortuño, J., Mateo, L., Rodríguez-Estrada, M. T., \& Bañón, S. (2021). Effects of sous vide vs grilling methods on lamb meat colour and lipid stability during cooking and heated display. Meat Science, $171,108287$.

36. Laplante, F., \& Duchesneau, L. (2011). ASTM D7454 Vibrated Bulk Density Method-Principles and Limitations. In Light Metals 2011 (pp. 953-957). Springer, Cham.

37. Ikewuchi, C. C. (2012). Hypocholesterolemic effect of an aqueous extract of the leaves of Sansevieria senegambica Baker on plasma lipid profile and atherogenic indices of rats fed egg yolk supplemented diet. EXCLI journal, 11, 346.

38. Sarabandi, K., Peighambardoust, S. H., \& Shirmohammadi, M. (2014). Physical properties of spray dried grape syrup as affected by drying temperature and drying aids. International Journal of Agriculture and Crop Sciences, 7(12), 928.

39. Condés, M. C., Añón, M. C., \& Mauri, A. N. (2015). Amaranth protein films prepared with high-pressure treated proteins. Journal of Food Engineering, 166, 38-44.

40. Menkiti, M. C., \& Ejimofor, M. I. (2016). Experimental and artificial neural network application on the optimization of paint effluent (PE) coagulation using novel Achatinoidea shell extract (ASE). Journal of Water Process Engineering, 10, 172-187.

41. Venkata, P., Sarat, K. S., \&Jayalaxmi, A. (2015). Comparison of Hybrid DifferentialEvolution Algorithm with GeneticAlgorithm Based Power System SecurityAnalysis Using FACTS.

42. Takagi, H., Maruyama, K., Yoshizawa, N., Yamada, Y., \& Sato, Y. (2004). XRD analysis of carbon stacking structure in coal during heat treatment. Fuel, 83(17-18), 2427-2433

43. Khusro, A. (2016). One Factor at A Time based optimization of protease from poultry associated Bacillus licheniformis. J. Appl. Pharm. Sci, 6(03), 088-095.

44. Zhao, Y. X., Gao, B. Y., Shon, H. K., Cao, B. C., \& Kim, J. H. (2011). Coagulation characteristics of titanium ( $\mathrm{Ti}$ ) salt coagulant compared with aluminum (Al) and iron (Fe) salts. Journal of hazardous 
materials, 185(2-3), 1536-1542

45. Zhao, Y. X., Phuntsho, S., Gao, B. Y., Yang, Y. Z., Kim, J. H., \& Shon, H. K. (2015). Comparison of a novel polytitanium chloride coagulant with polyaluminium chloride: coagulation performance and floc characteristics. Journal of environmental management, 147, 194-202.

46. Sun, Y., Zhou, S., Chiang, P. C., \& Shah, K. J. (2019). Evaluation and optimization of enhanced coagulation process: Water and energy nexus. Water-Energy Nexus, 2(1), 25-36.

\section{Figures}

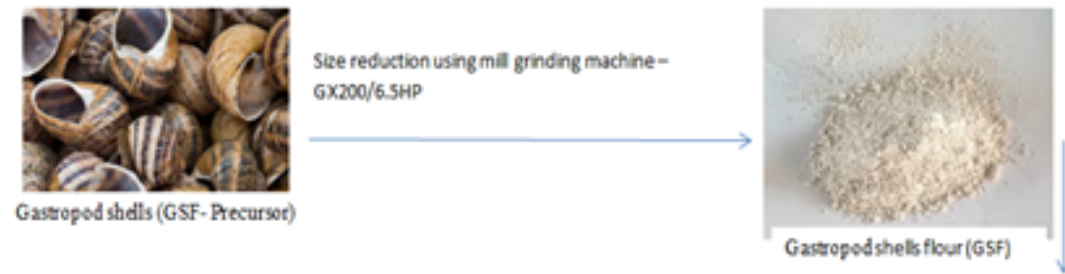

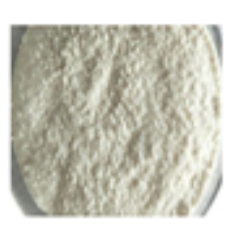

Gastropod Conchiolin

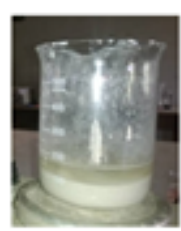

Filtrate (Conchiolin) concentration

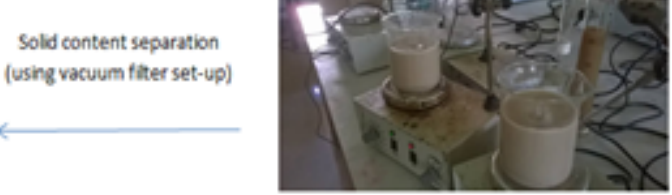

Deprotenization Experiment (Actual laboratory photograph)

\section{Figure 1}

Process route for conchiolin production

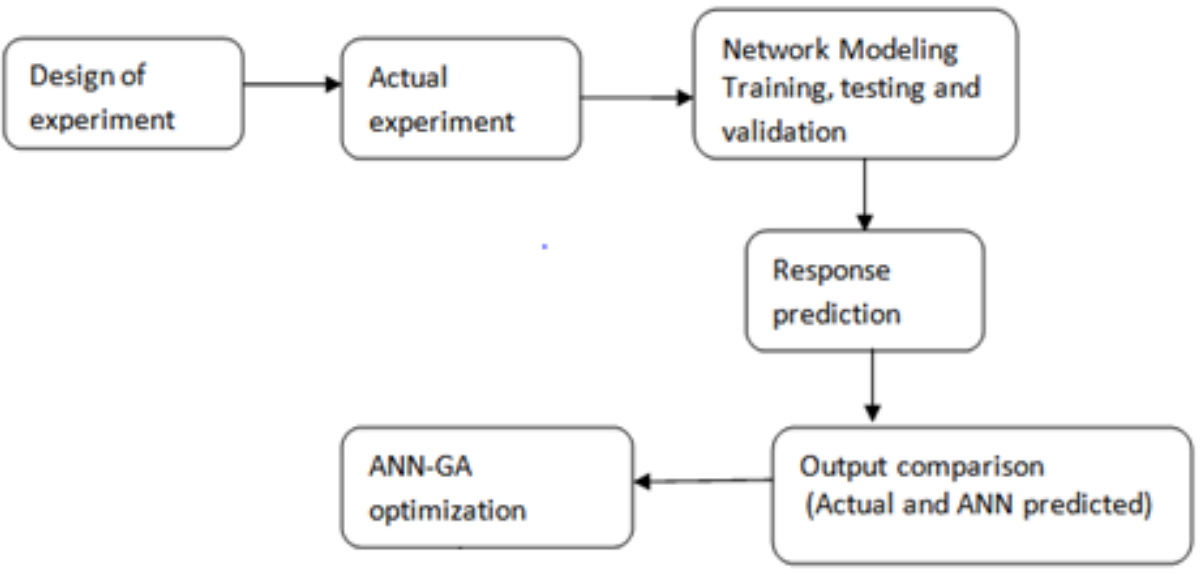

\section{Figure 2}

process route for ANN prediction and GA optimization 


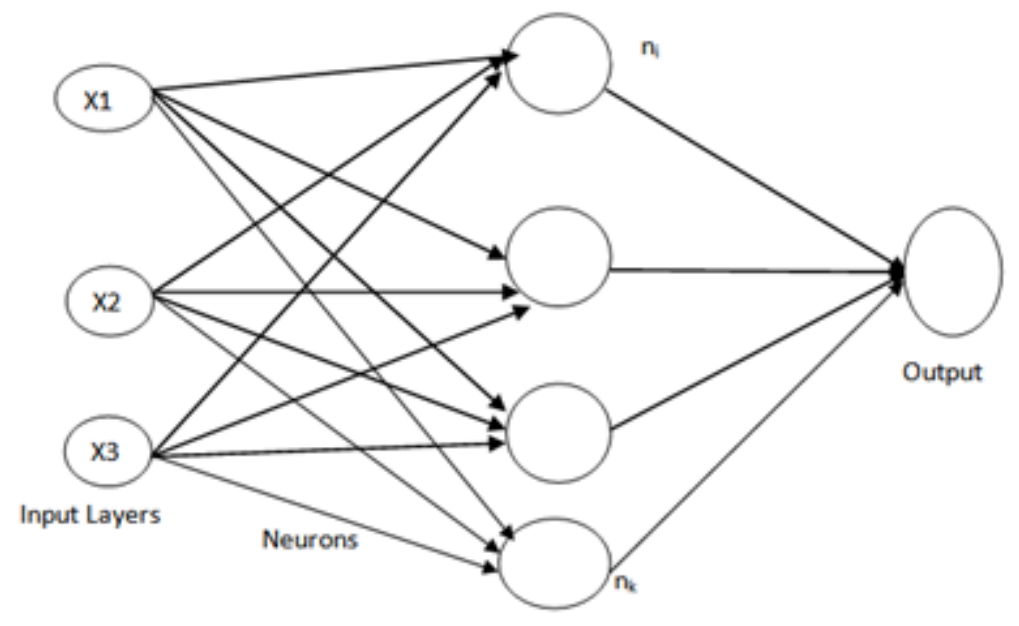

Hidden layers, $\mathrm{N}=\sum_{k=1}^{k} n_{k}$ )

Figure 3

Neural network architecture for input-hidden-output layers interaction

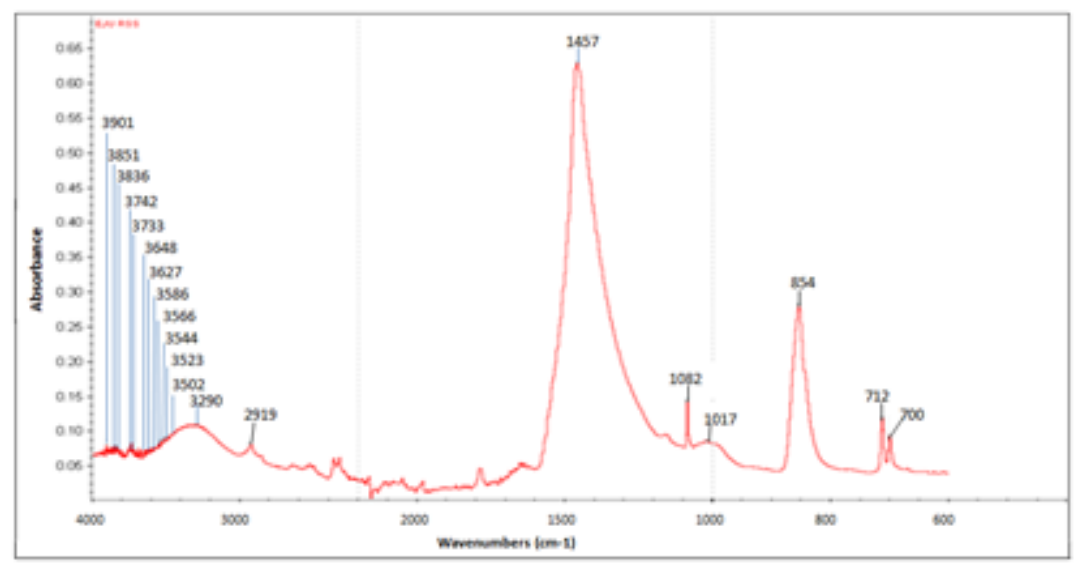

Figure 4

FTIR pattern of GSF

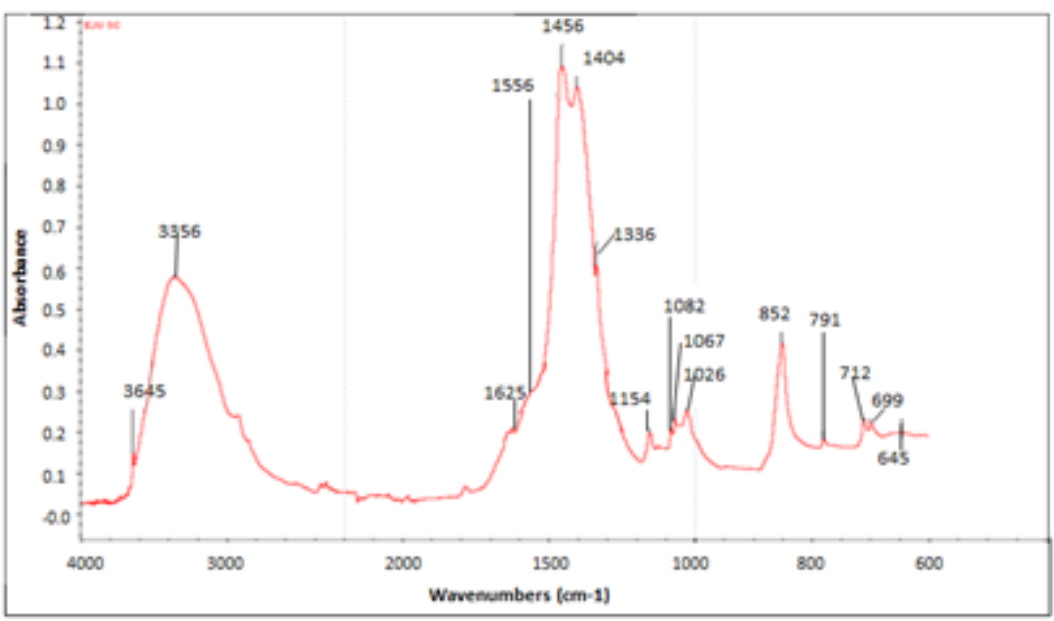

Page $22 / 29$ 
Figure 5

FTIR pattern of GSC

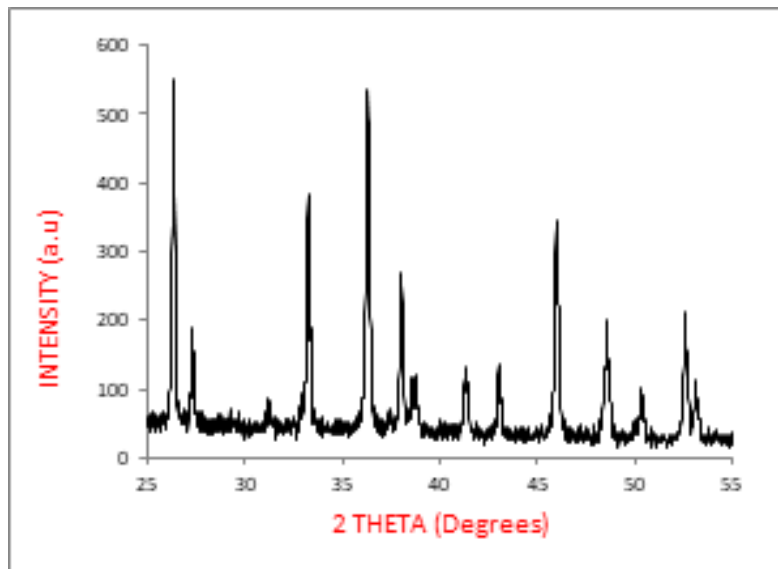

Figure 6

\section{XRD pattern of GSF}

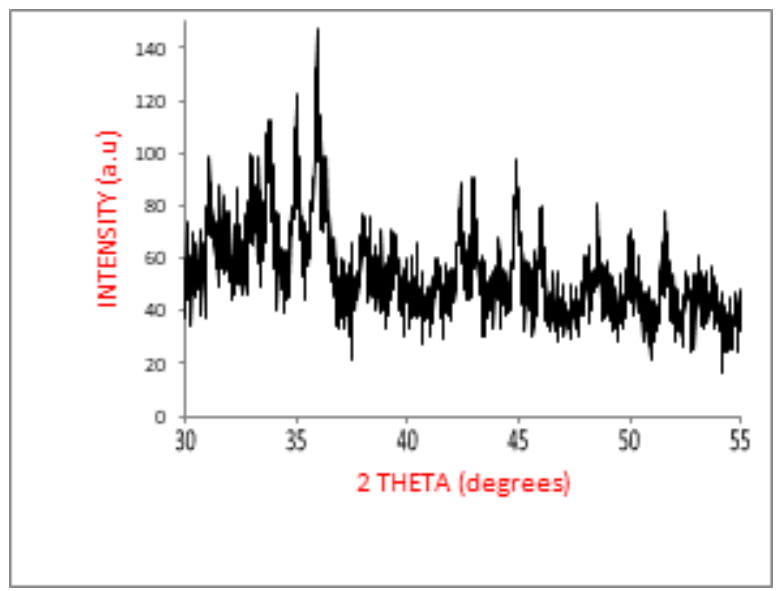

Figure 7

XRD pattern of GSC. 

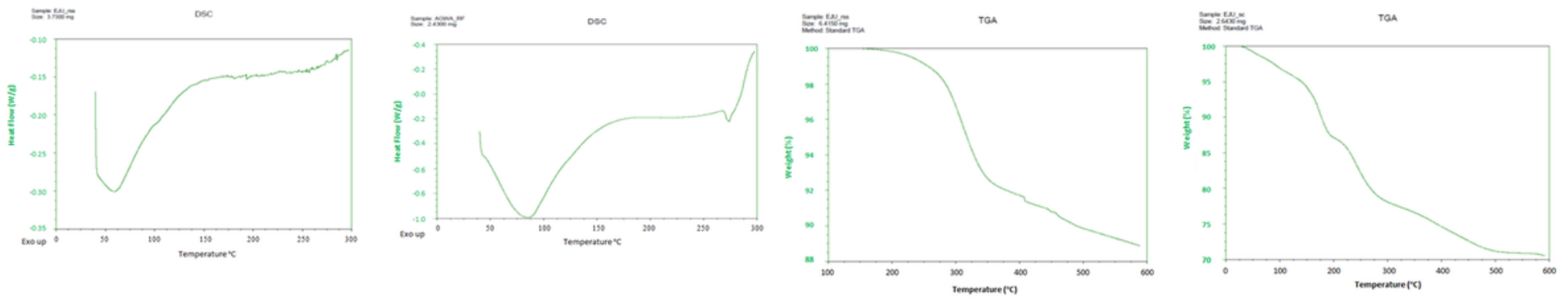

Figure 8

a: DSC profile of GSF.

b: DSC profile of GSC.

c: TGA profile of GSF.

d: TGA profile of GSC.

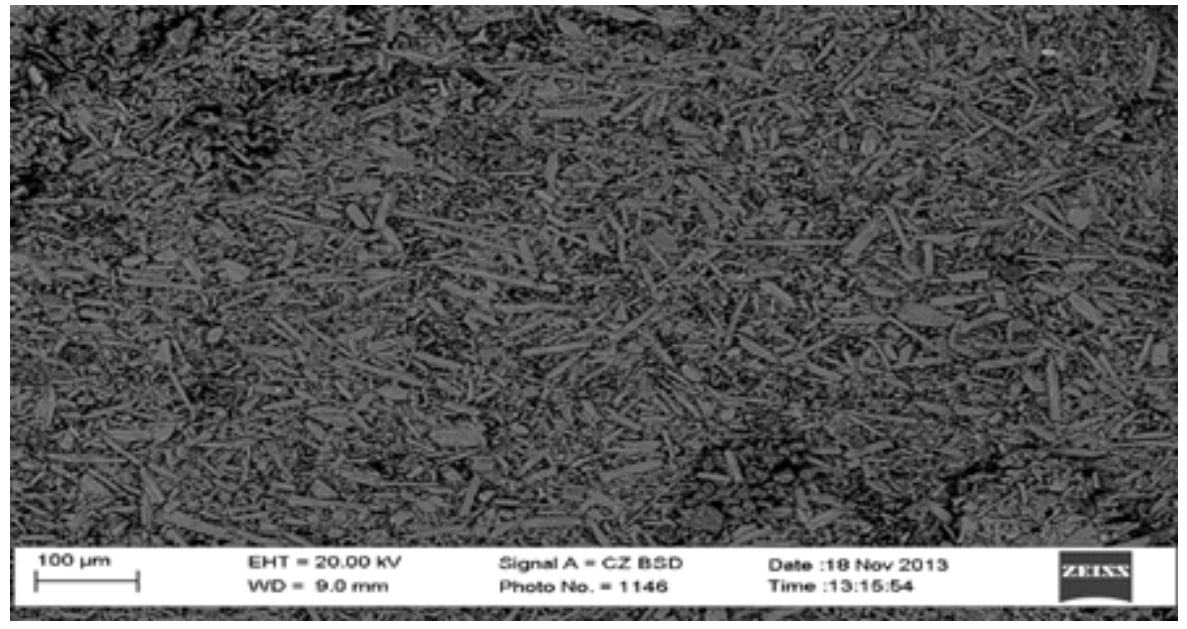

Figure 9

SEM Micrograph of GSC. 


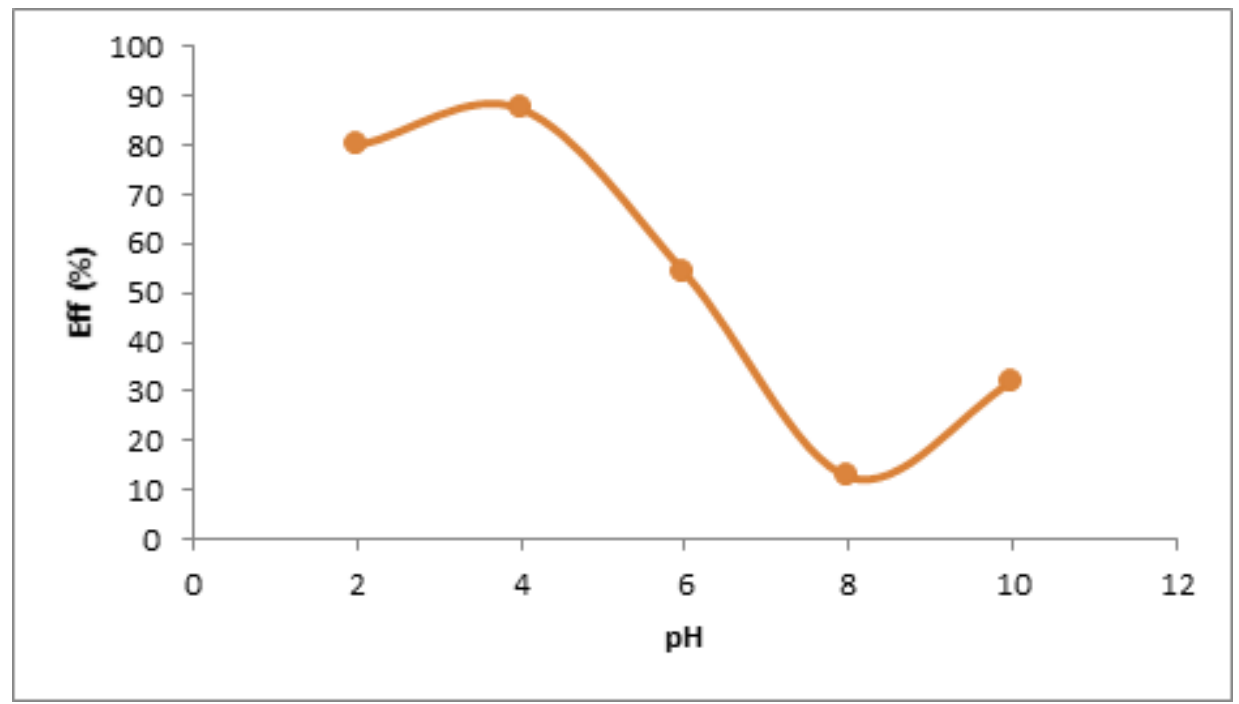

Figure 10

Plot of particle removal efficiency against $\mathrm{pH}$

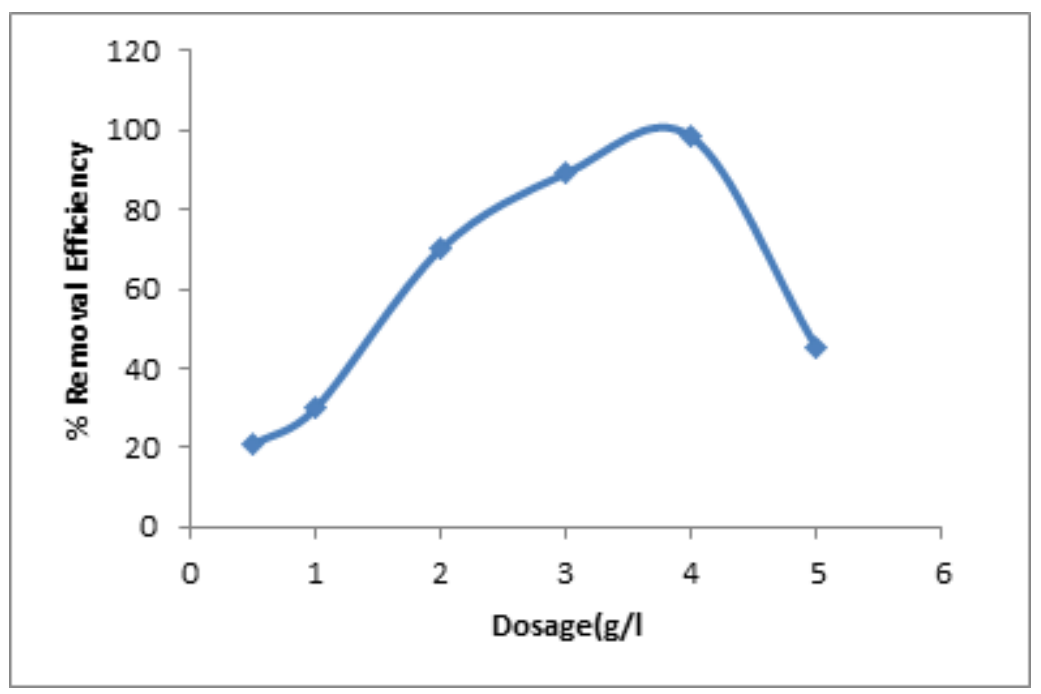

Figure 11

Plot of Eff. vs. Dosage at 30min 


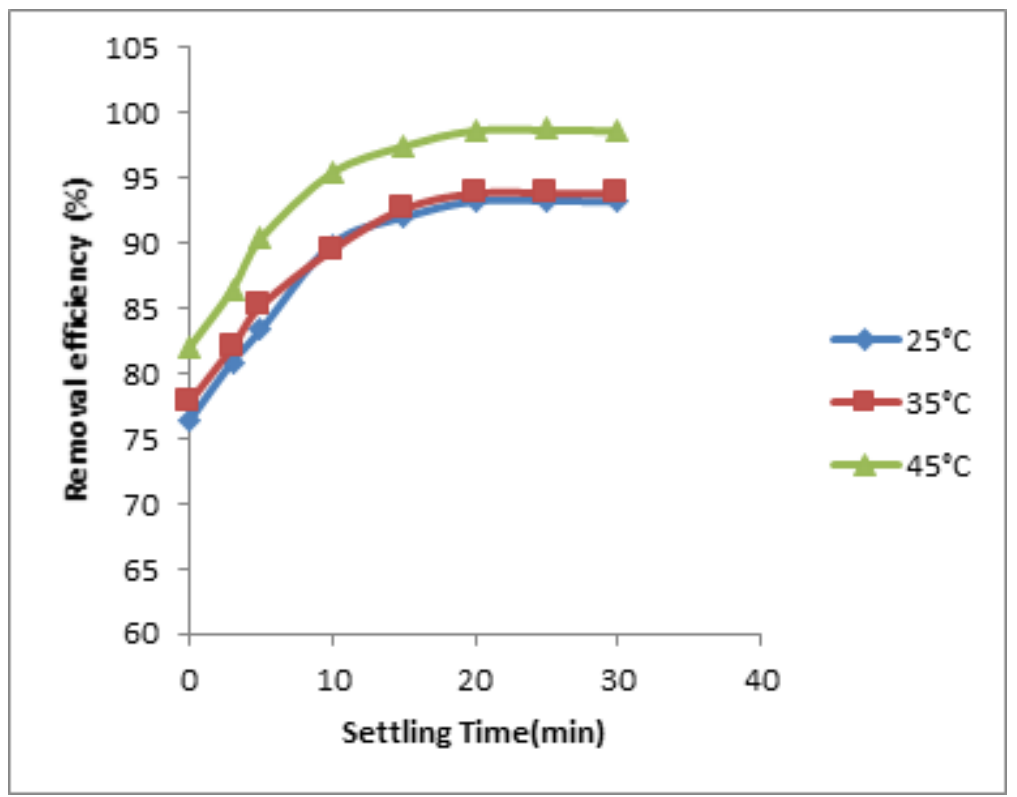

Figure 12

Variation of removal efficiency with settling time at $25^{\circ} \mathrm{C}, 35^{\circ} \mathrm{C}$ and $45^{\circ} \mathrm{C}$.

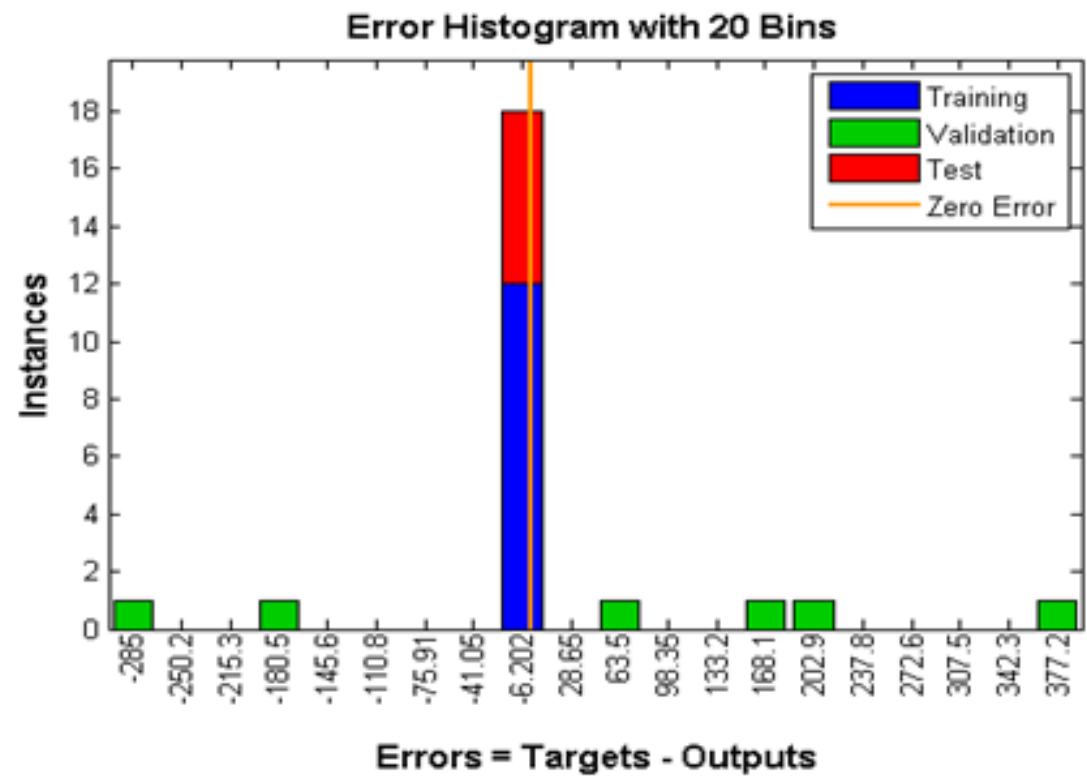

Figure 13

Error histogram for the network performance 


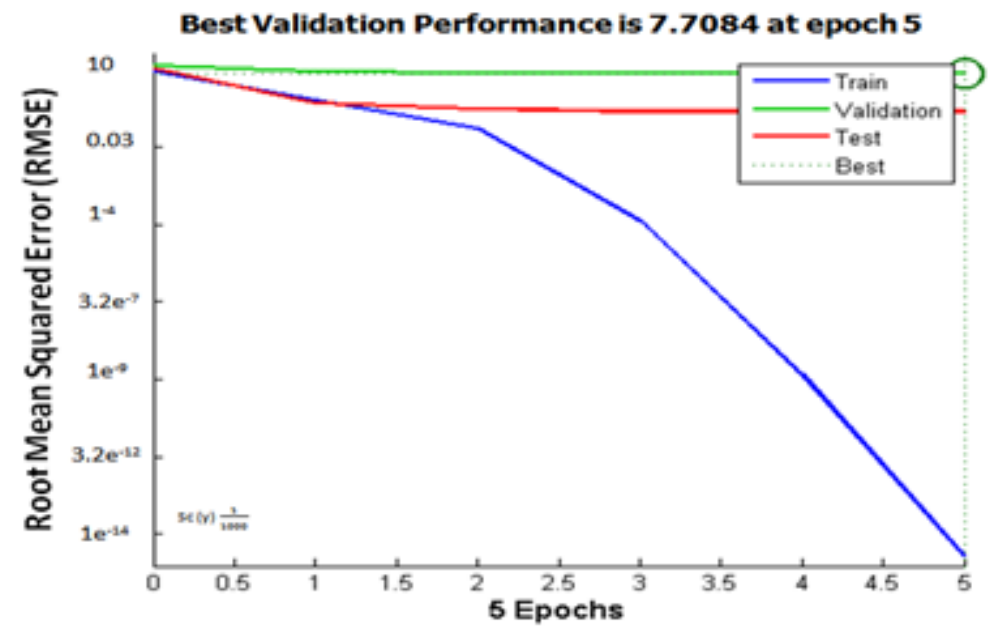

Figure 14

RMSE network performance curve
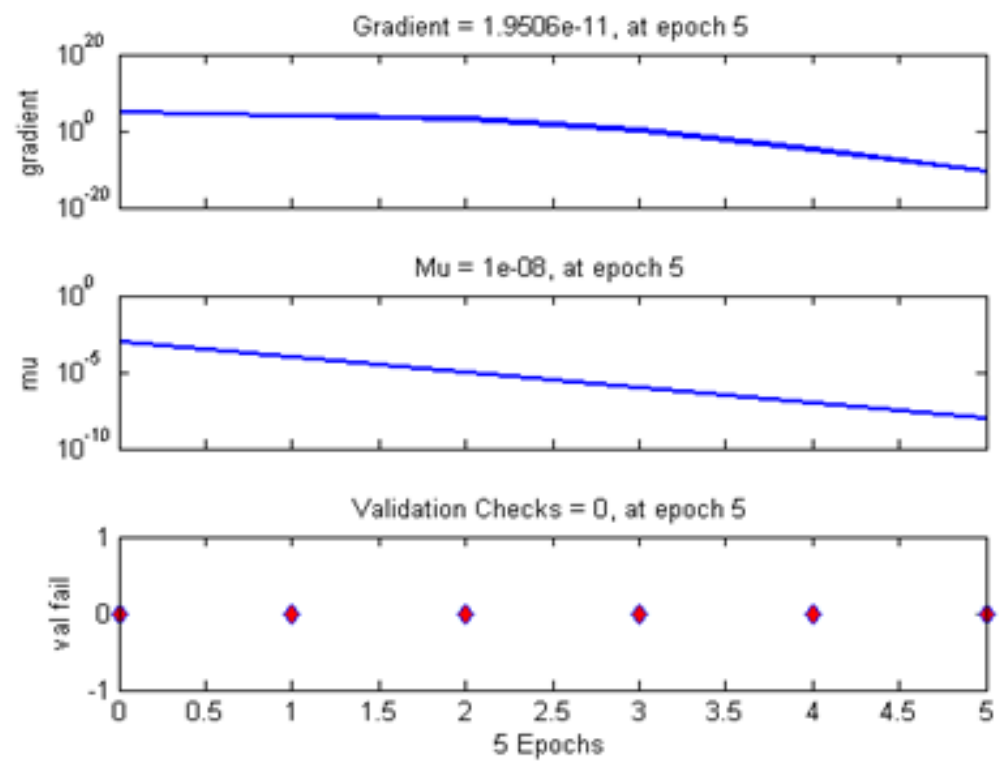

\section{Figure 15}

Training state for output prediction 

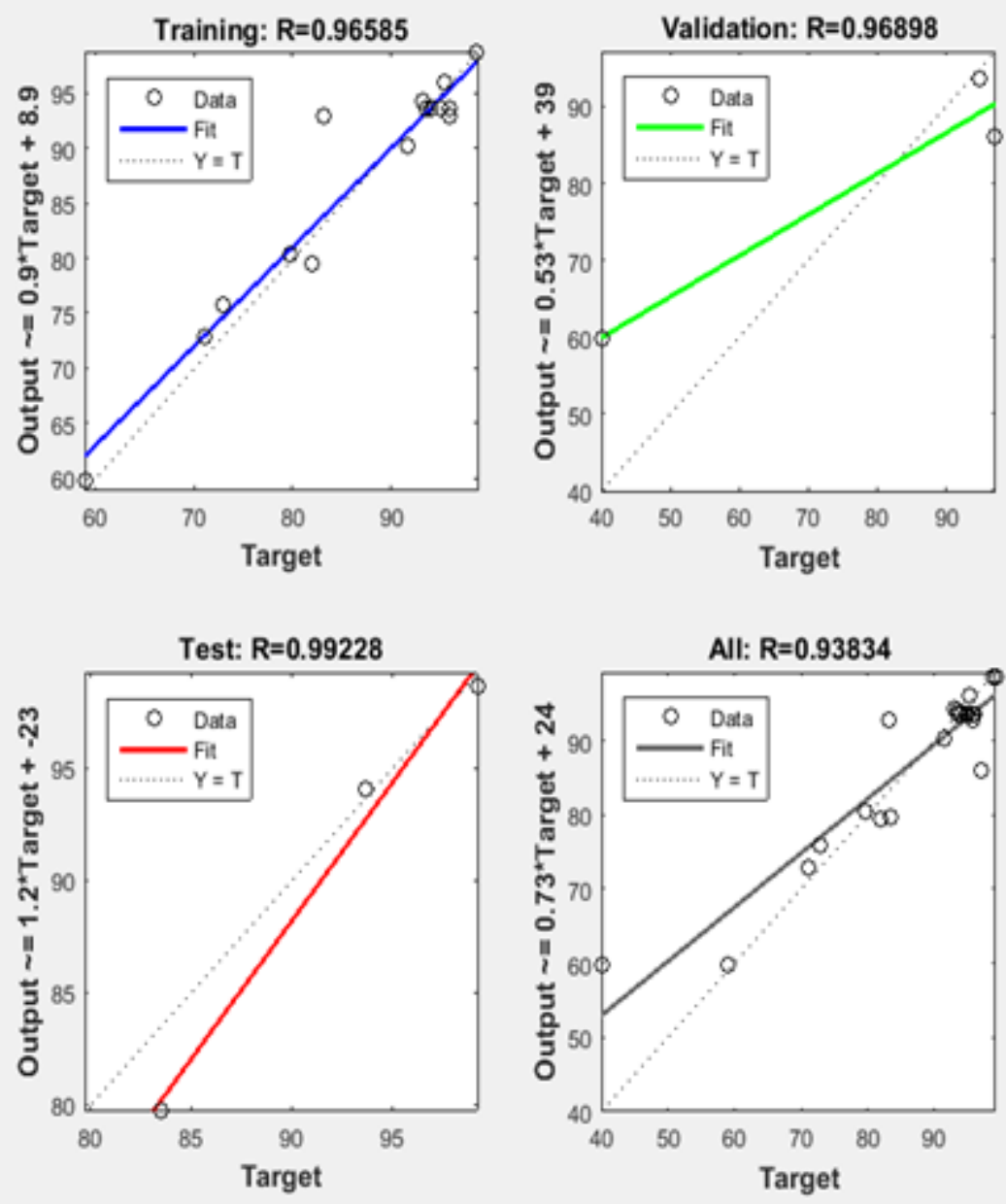

Figure 16

Performance plot of training, testing and validation

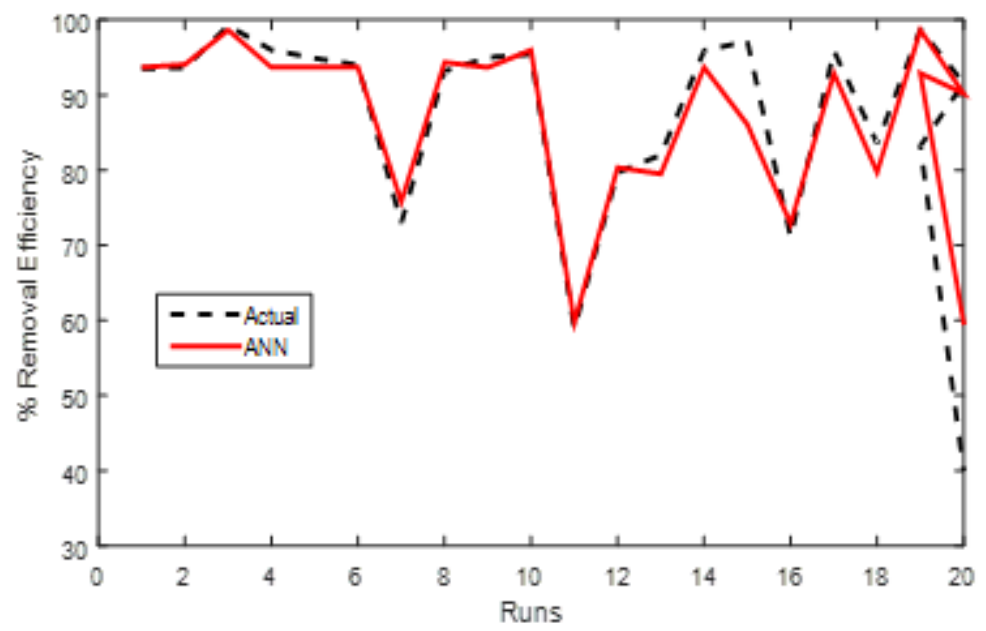

Figure 17

Experimental and ANN predicted responses with run order 
Page 29/29 